\title{
ANALISIS KEBIJAKAN PENGAMANAN OBJEK VITAL DI PT FREEPORT INDONESIA
}

\author{
Hasan Namudat ${ }^{1}$, Nina Karlina ${ }^{2}$, Budiman Rusli ${ }^{3}$ \\ Program Pasca Sarjana Kebijakan Publik \\ Fakultas Ilmu Sosial dan Ilmu Politik \\ Universitas Padjadjaran
}

hasannamudatt@gmail.com¹,nina.karlina@unpad.ac.id², budiman9560@gmail.com³

\begin{abstract}
ABSTRAK
Dewasa ini masalah keamanan dan ketertiban semakin strategis, hal ini terlihat dari dimensi ancaman dan gangguan terhadap keamanan dan ketertiban dari waktu ke waktu kian berkembang dengan beragam risiko dan dampaknya. Menyadari dampak gangguan keamanan obyek vital nasional bersifat nasional maka pemerintah mengeluarkan Keputusan Presiden Nomor 63 Tahun 2004 yang memberi kewenangan Kepolisian Republik Indonesia untuk melaksanakan pengamanan objek vital nasional dan melakukan audit sistem pengamanan objek vital nasional secara periodik. Namun hingga saat ini penanggulangan gangguan keamanan objek vital nasional, belum dikembangkan sebuah sistem koordinasi yang mencakup peran dan tugas masing-masing stakeholders. Padahal sistem koordinasi tersebut dibutuhkan agar penanggulangan gangguan keamanan objek vital nasional dapat dilakukan secara cepat dan efektif sehingga mampu memperkecil dampak keamanan yang ditimbulkannya.
\end{abstract}

Kata kunci Objek vital, kebijakan, keamanan

\section{ABSTRACT}

Today the issue of security and order is increasingly strategic, this can be seen from the dimensions of threats and disruptions to security and order from time to time increasingly developing with a variety of risks and impacts. Recognizing the impact of national vital object security disturbances on the national nature, the government issued Presidential Decree No. 63 of 2004 which authorized the Republic of Indonesia Police to carry out safeguards on national vital objects and periodically audited the security system of national vital objects. However, until now the response to the security of national vital objects has not yet been developed, a system of coordination that includes the roles and duties of each stakeholder. Even though the coordination system is needed so that the handling of security disturbances of national vital objects can be done quickly and effectively so as to minimize the security impacts that they cause.

Keywords Vital objects, policies, security

\section{PENDAHULUAN}

\section{Latar Belakang Masalah}

Keputusan Presiden Nomor 63 Tahun 2004 tentang Pengamanan Objek Vital Nasional juncto Undang-Undang Nomor 2 Tahun 2002 tentang Kepolisian Negara Republik Indonesia memerintahkan kepada jajaran Kepolisian Republik Indonesia untuk menyusun pedoman sistem pengamanan objek vital nasional sebagai upaya pemberian perlindungan, pengayoman dan pelayanan masyarakat.

Hal tersebut diperkuat dengan dikeluarkannya Surat Keputusan Kapolri Nomor Pol: Skep 783/X/2005 yang menjelaskan bahwa objek vital adalah kawasan, lokasi, bangunan, instalasi dan usaha yang bersifat strategis karena gangguan terhadap objek vital nasional tersebut sangat berpengaruh terhadap hajat orang banyak dan kepentingan nasional.
Pengaturan tentang pengamanan obyek vital nasional tersebut ditujukan untuk meminimalisir dan bahkan mencegah dampak gangguan dan ancaman terhadap objek vital nasional yang dapat mengakibatkan terjadinya bencana kemanusiaan, terganggunya pemerintahan, terancamnya keamanan dan pertahanan negara serta yang paling dihindari adalah rusaknya hasil pembangunan nasional.

Keputusan Presiden Nomor 63 Tahun 2004 merupakan kebijakan pengamanan obyek vital nasional yang berlaku untuk semua obyek vital nasional yang ada di Indonesia, termasuk di dalamnya PT Freeport Indonesia yang merupakan perusahaan asing yang sahamnya berasal dari berbagai negara, diantaranya Amerika, Australia, Jepang dan sebagainya, dengan kantor pusat berkedudukan di Jakarta dan lokasi tambang di Kecamatan Timika. 


\section{Analisis Kebijakan Pengamanan Objek Vital Di PT Freeport Indonesia (Hasan Namudat, Nina Karlina, Budiman Rusli)}

Pengamanan obyek vital nasional di PT Freeport Indonesia dirasakan urgent karena di lokasi pertambangan ini sering terjadi konflik-konflik yang biasanya dipicu oleh masalah air bersih, kerusakan lingkungan, pemberhentian karyawan PT Freeport Indonesia, bahkan sampai pada masalah pelanggaran hak asasi manusia. Masalah-masalah tersebut memicu konflik yang berkepanjangan di wilayah tersebut.

Konflik yang paling meresahkan bahkan sulit dihentikan di wilayah pertambangan PT Freeport Indonesia adalah konflik antar suku di wilayah ini. Hal tersebut ditengarai oleh kecemburuan sosial masyarakat adat suku Amugme terhadap 6 (enam) suku lainnya. Suku Amugme menganggap bahwa telah terjadi diskriminasi karena keenam suku lainnya tersebut bukanlah pemilik hak ulayat wilayah pertambangan PT Freeport Indonesia.

Berdasarkan Keputusan Presiden Nomor 63 Tahun 2004 juncto Surat Keputusan Menteri Energi dan Sumber Daya Mineral Nomor 1762 Tahun 2007 maka PT Freeport Indonesia melakukan hubungan kerjasama dengan pihak Kepolisian Republik Indonesia untuk menjaga dan menjamin keamanan di wilayah pertambangan. Antara PT Freeport Indonesia dengan Kepolisian Republik Indonesia melalui Polda Papua, dibuat Nota Kesepahaman atau MoU pada tanggal 8 Maret 2010.

Meskipun telah diatur sedemikian rupa, nyatanya selama berlakunya kebijakan pengamanan obyek vital di PT Freeport Indonesia hingga saat ini masih terjadi konflik dan gangguan keamanan di wilayah pertambangan tersebut. Praktik gangguan obyek vital PT Freeport Indonesia di Mimika merupakan bagian dari tata kelola pemerintahan yang belum cukup baik. Hal ini membuktikan bahwa secara faktual, negara melalui aparat keamanannya belum cukup tanggap dalam mengamankan wilayah pertambangan tersebut.

\section{Rumusan Masalah}

Bertolak dari paparan latar belakang masalah di atas, permasalahan dalam penelitian ini dirumuskan sebagai berikut: "Bagaimana analisis kebijakan pengamanan obyek vital nasional di PT Freeport Indonesia.”

\section{TINJAUAN TEORI}

\section{Kebijakan Publik}

Thomas R. Dye (1975) dalam Syafiie (2006:105) menyatakan bahwa, "Kebijakan publik adalah apapun juga yang dipilih pemerintah, apakah mengerjakan sesuatu atau tidak mengerjakan (mendiamkan) sesuatu itu (whatever government choose to do or not to do).” Sementara Carl Friedrich dalam Winarno (2007:17) mengemukakan bahwa, "Kebijakan sebagai suatu arah tindakan yang diusulkan oleh seseorang, kelompok atau pemerintah dalam suatu lingkungan tertentu yang memberikan hambatan-hambatan dan peluang-peluang terhadap kebijakan yang diusulkan untuk menggunakan dan mengatasi dalam rangka mencapai suatu tujuan atau merealisasikan suatu sasaran atau suatu maksud tertentu."

Winarno (2007:18) mengemukakan bahwa definisi yang lebih tepat mengenai kebijakan publik adalah sebagaimana definisi yang dikemukakan oleh James Anderson (1969) yaitu, "Kebijakan merupakan arah tindakan yang mempunyai maksud yang ditetapkan oleh seorang aktor atau sejumlah aktor dalam mengatasi suatu masalah atau suatu persoalan.”

Winarno (2007:19), dengan mengkomparasi berbagai definisi yang dikemukakan oleh para ahli yang menaruh minat dalam kebijakan publik mengemukakan bahwa pada dasarnya pandangan mengenai kebijakan publik dapat dibagi ke dalam dua wilayah kategori yaitu, "Pertama, pendapat ahli yang menyamakan kebijakan publik dengan tindakan-tindakan pemerintah. Para ahli dalam kelompok ini cenderung menganggap bahwa semua tindakan pemerintah dapat disebut sebagai kebijakan publik. Kedua, berangkat dari para ahli yang memberikan perhatian khusus kepada pelaksanaan kebijakan. Para ahli yang masuk dalam kategori ini terbagi dalam dua kubu, kubu pertama melihat kebijakan publik dalam tiga lingkungan, yakni perumusan kebijakan, pelaksanaan kebijakan dan penilaian dan kubu kedua memandang kebijakan publik sebagai suatu hipotesis yang mengandung kondisi-kondisi awal dan akibat-akibat yang bisa diramalkan.”

Lebih lanjut, Syafiie (2006:106) mengemukakan bahwa pengertian kebijakan publik dapat dirumuskan sebagai, "Pengetahuan tentang kebijakan publik adalah pengetahuan tentang sebab-sebab, konsekuensi dan kinerja kebijakan serta program publik, sedangkan pengetahuan dalam kebijakan publik adalah proses menyediakan informasi dan pengetahuan untuk para eksekutif, anggota legislatif, lembaga peradilan dan masyarakat umum yang berguna dalam proses perumusan kebijakan serta yang dapat meningkatkan kinerja kebijakan.”

\section{Analisis Kebijakan Menurut Dunn}

William N. Dunn (2013:1) menjelaskan bahwa, "Analisis kebijakan publik adalah suatu disiplin ilmu sosial, terapan, yang menggunakan berbagai macam metodologi penelitian dan argumen untuk menghasilkan dan mentransformasikan informasi yang relevan dengan kebijakan, yang digunakan dalam 
lingkungan politik tertentu, untuk memecahkan masalah-masalah kebijakan.”

Lebih jauh, Dunn (2013) menjelaskan beberapa aspek yang harus diperhatikan dalam analisis kebijakan yaitu sebagai berikut.

a. Perumusan Masalah

Perumusan masalah merupakan kegiatan yang paling penting dari para analis kebijakan karena perumusan masalah merupakan sistem petunjuk pokok atau mekanisme pendorong yang mempengaruhi keberhasilan semua fase analisis kebijakan. Analisis kebijakan ditujukan dan diarahkan secara seimbang kepada perumusan masalah dan pemecahan masalah.

b. Peramalan Masa Depan Kebijakan

Dunn (2013:291) menjelaskan bahwa, "Peramalan atau forecasting adalah suatu prosedur untuk membuat informasi faktual tentang situasi sosial di masa depan atas dasar informasi yang telah ada tentang masalah kebijakan.” Lebih lanjut Dunn (2013:291) menerangkan pula bahwa, "Tujuan daripada diadakannya peramalan kebijakan adalah untuk memperoleh informasi mengenai perubahan di masa yang akan datang yang akan mempengaruhi terhadap implementasi kebijakan serta konsekuensinya.”

c. Rekomendasi Kebijakan

Menurut Dunn (2013:405), "Prosedur dari analisis kebijakan dari rekomendasi memungkinkan menghasilkan informasi tentang kemungkinan serangkaian aksi di masa mendatang untuk menghasilkan konsekuensi yang berharga bagi individu, kelompok atau masyarakat seluruhnya.” Untuk merekomendasikan suatu tindakan kebijakan khusus diperlukan adanya informasi tentang konsekuensikonsekuensi di masa depan setelah dilakukannya berbagai alternatif tindakan.

d. Pemantauan Hasil Kebijakan

Dunn (2013:509) menerangkan bahwa, "Pemantauan hasil kebijakan atau biasa disebut monitoring merupakan prosedur analisis kebijakan yang digunakan untuk memberikan informasi tentang sebab akibat kebijakan publik.” Lebih jauh Dunn (2013:510-511) menjelaskan bahwa, "Pemantauan setidaknya memainkan empat fungsi dalam analisis kebijakan yaitu kepatuhan (compliance), akuntansi, pemeriksaan, dan ekplanasi. Hasil kebijakan dibedakan antara keluaran (outputs), yaitu produk layanan yang diterima kelompok sasaran kebijakan, dan impak (impact), yaitu perubahan perilaku yang nyata pada kelompok sasaran kebijakan.”

e. Evaluasi Kinerja Kebijakan

Menurut Dunn (2013:632), “Fungsi evaluasi dalam analisis kebijakan adalah menyediakan informasi yang valid dan dapat dipercaya mengenai kinerja kebijakan, kemudian memberikan kejelasan dan kritik nilai-nilai yang mendasari pilihan tujuan, sasaran, dan penyediaan informasi bagi perumusan masalah dan inferensi praktis.” Evaluasi kinerja kebijakan dilakukan untuk menilai hasil yang dicapai oleh suatu kebijakan setelah dilaksanakan.

Berdasarkan uraian tersebut mengenai analisis kebijakan peneliti dapat mengambil kesimpulan bahwa dalam prosesnya analisis kebijakan terbagi ke dalam beberapa tahap analisis. Untuk itu dalam proses penelitian mengenai kebijakan pengamanan obyek vital PT Freeport Indonesia peneliti akan menggunakan teori yang ditawarkan Dunn sebagai pisau analisis kebijakan.

\section{Pengamanan Obyek Vital Nasional}

Obyek vital nasional mempunyai peran yang cukup strategis dalam pembangunan nasional. Di lain pihak, dimensi ancaman dan gangguan keamanan semakin berkembang dengan beragam risiko dan dampaknya. Ancaman dan gangguan keamanan terhadap obyek vital nasional secara langsung maupun tidak langsung berdampak pada sistem perekonomian nasional, stabilitas politik, serta keamanan nasional.

Dalam Keputusan Presiden Nomor 63 Tahun 2004 disebutkan bahwa obyek vital nasional adalah kawasan/lokasi/bangunan/instalasi dan/atau usaha yang menyangkut hajat hidup orang banyak, kepentingan negara, dan/atau sumber pendapatan negara yang bersifat strategis. Mengingat peranannya yang cukup strategis, obyek vital nasional membutuhkan sistem pengamanan yang lebih kuat dan didasarkan atas standar sistem pengamanan yang ketat, sehingga mampu memperkecil risiko dan dampak keamanan yang ditimbulkan akibat adanya ancaman dan gangguan keamanan.

Pasal 5 Keputusan Presiden Nomor 63 Tahun 2004 menjelaskan ciri-ciri obyek vital nasional sebagai berikut:

a. Ancaman dan gangguan terhadapnya mengakibatkan bencana terhadap kemanusiaan dan pembangunan. 
b. Ancaman dan gangguan terhadapnya mengakibatkan kekacauan transportasi dan komunikasi secara nasional.

c. Ancaman dan gangguan terhadapnya mengakibatkan terganggunya penyelenggaraan pemerintahan negara.

Keputusan Presiden Nomor 63 Tahun 2004 menerangkan juga bahwa konfigurasi standar pengamanan setiap obyek vital nasional harus memenuhi standar kualitas atau kemampuan yang ditetapkan oleh Kepolisian Negara Republik Indonesia serta melaksanakan secara periodik audit sistem pengamanan.

\section{METODE PENELITIAN}

Metode penelitian yang digunakan dalam penelitian ini adalah penelitian kualitatif. Moleong (2010:6) menjelaskan bahwa, "Penelitian kualitatif adalah suatu penelitian yang ditujukan untuk mendeskripsikan dan menganalisis fenomena, peristiwa, aktivitas sosial, sikap, kepercayaan, persepsi, pemikiran orang secara individual maupun kelompok.”

Dalam penelitian ini menggunakan data primer dan data sekunder. Sumber data primer adalah sumber data yang diperoleh dari wawancara dengan informan atau obyek yang diteliti, sedangkan menurut Maleong (2010:157) sumber data sekunder adalah sumber data yang diperoleh melalui dokumen-dokumen tertulis, arsip maupun yang lainnya pada instansi yang berhubungan dengan penelitian. Pengumpulan data menggunakan pendekatan kualitatif di mana peneliti sendiri sebagai instrumen dalam penelitian dengan menggunakan observasi, wawancara, serta studi kepustakaan.

Setelah pengumpulan data yang diperlukan, penulis melakukan analisis melalui beberapa tahapan analisis, diantaranya:

1. Hasil wawancara, observasi, dan studi pustaka dikategorikan dan mereduksi data yang berhubungan dengan proses pengorganisasian, interprestasi, dan aplikasi kebijakan pengamanan obyek vital di PT Freeport Indonesia.

2. Bentuk rangkaian informasi yang memiliki makna sesuai dengan proses pengamanan obyek vital, dikelompokkan dalam data yang selanjutnya disusun menjadi narasi-narasi.

3. Menginterpretasikan data yang telah dikelompokkan berdasarkan hasil kategori dan reduksi, sehingga mendapat makna yang sebenarnya sebagai memberikan jawaban atas masalah yang diteliti.

4. Menyimpulkan implementasi kebijakan pengamanan obyek vital nasional pada PT Freeport Indonesia di Kabupaten Mimika. Berdasarkan susunan narasi data dengan informan, yang didasarkan pada tahap kesimpulan.

5. Melakukan verifikasi hasil analisis data dengan informan, yang didasarkan pada tahap kesimpulan.

\section{PEMBAHASAN}

Analisis data dan temuan di lapangan yang peneliti dapati dianalisis dengan menggunakan metode analisis kebijakan yang ditawarkan Dunn (2013) yang menggunakan lima indikator tahapan yaitu pencarian permasalahan, peramalan, rekomendasi kebijakan, monitoring, dan evaluasi. Berikut penjabarannya.

\section{Perumusan Masalah}

Dunn (2013:26) menjelaskan bahwa, "Perumusan masalah dapat membantu menemukan asumsi-asumsi yang tersembunyi, mendiagnosis penyebab-penyebabnya, memetakan tujuan-tujuan yang memungkinkan memadukan pandanganpandangan yang bertentangan, dan merancang peluang-peluang kebijakan yang baru.” Perumusan masalah merupakan langkah awal dalam pembuatan suatu kebijakan publik. Kebijakan publik dibuat dikarenakan adanya masalah publik yang terjadi, sehingga permasalahan tersebut dapat diantisipasi dan mencapai tujuan yang diharapkan.

Berdasarkan hasil wawancara dan observasi yang peneliti lakukan dalam proses pencarian masalah tentang pengamanan obyek vital nasional di PT Freeport Indonesia, peneliti menemukan permasalahan yang terjadi adalah sebagai berikut:

a. Masih kurangnya koordinasi pengamanan antara pihak perusahaan dengan Kepolisian, sehingga bila terjadi gangguan keamanan, maka sulit bagi Kepolisian untuk masuk ke lokasi obyek vital nasional.

b. Masih kurangnya pemahaman sistem pengamanan yang harus dilaksanakan oleh petugas keamanan.

c. Pihak perusahaan masih belum peduli terhadap konfigurasi standar pengamanan.

d. Sistem pengamanan obyek vital nasional masih di bawah standar.

e. Sarana prasarana pengamanan Kepolisian masih terbatas atau belum tercukupi.

f. Personil pengamanan Kepolisian yang masih terbatas.

g. Belum dimanfaatkannya teknologi moderen/canggih dalam sistem pengamanan.

h. Pihak perusahaan dan Kepolisian masih kurang peduli terhadap potensi lingkungan sosial untuk pelaksanaan pengamanan obyek vital nasional. 


\section{Peramalan Masa Depan Kebijakan}

Langkah selanjutnya setelah melakukan pencarian masalah yaitu melakukan sebuah peramalan mengenai sebuah kebijakan yang sedang berlangsung. Dalam penelitian mengenai analisis kebijakan pengamanan obyek vital nasional di PT Freeport Indonesia, peramalan atau forcesting dilakukan untuk melihat sejauh mana dan seperti apa perkembangan dari proses pengamanan obyek vital nasional di PT Freeport Indonesia.

Berdasarkan hasil wawancara dan observasi yang peneliti lakukan dalam proses peramalan masa depan kebijakan diperoleh data bahwa pembenahan fasilitas pengamanan, penambahan personel pengamanan, penyediaan sarana dan prasarana, perbaikan standar pengamanan obyek vital, serta mempersiapkan kondisi sosial masyarakat di Timika menjadi lima poin yang saling berhubungan dalam proses kebijakan pengamanan obyek vital nasional di PT Freeport Indonesia.

\section{Rekomendasi Kebijakan}

Rekomendasi kebijakan merupakan langkah selanjutnya yang dilakukan dalam proses analisis kebijakan, setelah mengetahui bagaimana masalah yang terjadi, dan kemudian melakukan sebuah peramalan untuk masa depan, maka langkah selanjutnya yaitu memberikan sebuah rekomendasi kebijakan terhadap apa yang menjadi persoalan dalam kasus tersebut, sehingga rekomendasi kebijakan bertujuan untuk menjawab dan menyelesaikan permasalahan yang ada.

Berdasarkan hasil wawancara dan observasi yang peneliti lakukan dalam proses rekomendasi kebijakan diperoleh keterangan bahwa masih diperlukan regulasi teknis terkait dengan sistem pengamanan obyek vital nasional di PT Freeport Indonesia. Selain itu, masih diperlukan peningkatan kemampuan personel Kepolisian dalam menjaga obyek vital nasional tersebut.

Berkaitan dengan regulasi teknis pengamanan obyek vital, maka diperlukan pengaturanpengaturan yang berhubungan dengan pengamanan internal oleh perusahaan, perencanaan pengamanan, standar dan prosedur pengamanan, kualifikasi personel tenaga pengamanan, teknologi pengamanan, sistem kerjasama dan koordinasi dengan aparat Kepolisian, kerjasama pengamanan swakarsa dengan masyarakat dan stakeholders, pengawasan dan pengendalian, evaluasi berkala, serta perbaikan sistem pengamanan.

Dalam hubungannya dengan peningkatan kemampuan personel keamanan, maka perlu secara bertahap Kepolisian meningkatkan jumlah personil yang akan ditugaskan untuk mendukung sistem pengamanan obyek vital nasional di PT Freeport Indonesia. Pelibatan TNI dan Satpol PP harus disinkronkan dengan tugas dan wewenang Kepolisian, sehingga sesuai dengan Tupoksinya masing-masing. Sedangkan untuk meningkatkan kemampuan personil pengamanan obyek vital nasional, maka Kepolisian dapat menyelenggarakan pendidikan dan pelatihan khusus untuk kebutuhan sistem pengamanan obyek vital nasional.

\section{Pemantauan Hasil Kebijakan}

Monitoring atau pemantauan kebijakan merupakan langkah selanjutnya dalam proses analisis kebijakan yang dilakukan peneliti. Dalam sebuah kebijakan tentu sebuah proses pemantauan kebijakan sagatlah diperlukan karena bertujuan untuk mengetahui bagaimana proses kebijakan tersebut berjalan. Monitoring atau pemantauan pelaksanaan kebijakan pengamanan obyek vital nasional di PT Freeport Indonesia ini dilakukan oleh seluruh instansi yang terlibat dalam program pengamanan obyek vital nasional di PT Freeport Indonesia.

Berdasarkan hasil wawancara dan observasi yang peneliti lakukan dalam proses monitoring atau pemantauan kebijakan diperoleh data bahwa monitoring memang telah dilakukan namun hasilnya terkadang tidak menjadi sebuah masukan terhadap pembahasan yang dilakukan setiap kebijakan yang diambil oleh pemerintah.

\section{Evaluasi Kinerja Kebijakan}

Evaluasi kebijakan merupakan langkah terakhir dalam proses analisis kebijakan yang dilakukan oleh peneliti. Tujuan dari evaluasi kebijakan dalam proses analisis kebijakan bertujuan untuk melihat dan menilai apa yang mendasari tujuan, sasaran dan kinerja dari kebijakan tersebut. Dalam penelitian mengenai analisis kebijakan pengamanan obyek vital di PT Freeport Indonesia, peneliti banyak mendapatkan informasi terkait persoalan evaluasi kebijakan yang kemudian akan dilaksankan.

Berdasarkan hasil wawancara dan observasi yang peneliti lakukan dalam proses evaluasi kinerja kebijakan ditemukan data bahwa proses teknis evaluasi sebetulnya menjadi tanggung jawab dari seluruh pemangku kebijakan yang terlibat dalam proses pengamanan obyek vital nasional di PT Freeport Indonesia, namun untuk permasalahan yang terjadi dalam lingkup penyediaan sarana dan prasarana pengamanan, kelembagaan organisasi dan koordinasi tentu 
itu menjadi tugas Pemerintah Pusat dan Daerah serta perusahaan. Oleh karena itu, proses evaluasi dan monitoring tentunya harus dilakukan oleh seluruh stakeholders, sehingga progres dari rencana aksi yang akan disusun selanjutnya dapat terealisasi dengan baik.

Kebijakan sistem pengamanan obyek vital nasional di PT Freeport Indonesia sekarang ini masih belum optimal. Pengamanan obyek vital nasional di wilayah pertambangan ini masih belum memiliki sistem pengamanan yang sesuai standar dengan standar yang telah ditetapkan, serta rawan terhadap ancaman gangguan keamanan, seperti ancaman serangan OPM yang dapat berdampak serius terhadap keamanan nasional. Oleh karena itu, masih diperlukan perbaikan-perbaikan kebijakan yang mengatur pengamanan obyek vital nasional di PT Freeport Indonesia.

\section{KESIMPULAN}

Berdasakan pada hasil analisis dan temuan lapangan yang telah peneliti sampaikan di atas, maka peneliti menyimpulkan bahwa dalam proses kebijakan pengamanan obyek vital nasional di PT Freeport belum dilaksanakan secara baik dan maksimal. Hal ini dikarenakan masih banyaknya persoalan yang belum dilaksanakan dengan optimal seperti kelembagaan, regulasi dan koordinasi. Berikut peneliti simpulkan hasil penelitian dari analisis kebijakan pengamanan obyek vital nasional di PT Freeport Indonesia.

1. Dalam tahap perumusan masalah, ditemukan beberapa persoalan seperti masih kurangnya koordinasi pengamanan antara pihak perusahaan dengan Kepolisian, masih kurangnya pemahaman sistem pengamanan yang harus dilaksanakan oleh petugas keamanan, pihak perusahaan masih belum peduli terhadap konfigurasi standar pengamanan, sistem pengamanan obyek vital nasional masih di bawah standar, sarana prasarana pengamanan Kepolisian masih terbatas atau belum tercukupi, personil pengamanan Kepolisian yang masih terbatas, belum dimanfaatkannya teknologi moderen/canggih dalam sistem pengamanan, serta pihak perusahaan dan Kepolisian masih kurang peduli terhadap potensi lingkungan sosial untuk pelaksanaan pengamanan obyek vital nasional.

2. Pada proses peramalan, terlihat banyak hal yang perlu dibentuk dan dibenahi agar tidak menjadi permasalahan yang justru akan merugikan. Permasalahan seperti pembenahan fasilitas pengamanan, penambahan personel pengamanan, penyediaan sarana dan prasarana, perbaikan standar pengamanan obyek vital, serta mempersiapkan kondisi sosial masyarakat di Timika menjadikan pengamanan obyek vital nasional di PT Freeport Indonesia belum berjalan lancar.

3. Pada proses tahapan rekomendasi kebijakan, dalam keberlangsungan pengamanan obyek vital nasional di PT Freeport Indonesia, Pemerintah harus segera membuat sebuah regulasi teknis dengan membuat arahan-arahan kebijakan tentang sistem pengamanan terpadu obyek vital nasional di PT Freeport Indonesia. Untuk itu, masukan terhadap rekomendasi kebijakan yang telah diberikan ke depannya agar segera dilakukan supaya persoalan yang sebelumnya terjadi tidak terulang di masa yang akan datang dan akan berjalan dengan optimal.

4. Pada pemantauan kebijakan atau pada tahap monitoring, kasus mengenai pengamanan obyek vital nasional di PT Freeport Indonesia tidak hanya menjadi tanggung jawab dari pemerintah Pusat melainkan tanggung jawab dari seluruh elemen yang terlibat, baik Pemerintah Pusat, Pemerintah Daerah, perusahaan maupun masyarakat juga harus turut andil dalam mengawasi jalannya proses pengamanan obyek vital nasional di PT Freeport.

5. Pada tahapan akhir dalam analisis kebijakan yaitu evaluasi. Dalam tahapan ini, evaluasi dalam proses pengamanan obyek vital nasional di PT Freeport Indonesia sebetulnya telah dilakukan beberapa kali sesuai dengan kronologis kebijakan yang berlangsung. Namun, evaluasi dilakukan oleh seluruh stakeholders tidak memberikan sebuah efek yang baik karena masih saja terjadi konflik dan ancaman serta gangguan terhadap obyek vital nasional di PT Freeport Indonesia.

\section{DAFTAR PUSTAKA}

Dunn, William. N. (2013). Pengantar Analisis Kebijakan Publik. Yogyakarta: Gadjah Mada University Press.

Indiahono, Dwiyanto. (2009). Kebijakan Publik Berbasis Dynamic Policy Analysis. Yogyakarta: Gaya Media.

Islamy, M. Irfan. (2007). Prinsip-prinsip Perumusan Kebijakan Negara. Jakarta: Bumi Aksara.

Moleong, Lexy. J. (2010). Metodologi Penelitian Kualitatif. Bandung: Remaja Rosdakarya.

Pasolong, Harbani. (2008). Teori Administrasi Publik. Bandung: Alfabeta.

Syafiie, Inu Kencana. (2006). Sistem Administrasi publik Republik Indonesia (SANKRI). Jakarta: Bumi Aksara.

Widodo, Joko. (2007). Analisa Kebijakan Publik. Malang: Bayu Media Publishing.

Winarno, Budi. (2007). Teori dan Proses Kebijakan Publik. Yogyakarta: Media Pressindo. 